\title{
Participating Country Code
}

National Cancer Institute

\section{Source}

National Cancer Institute. Participating Country Code. NCI Thesaurus. Code C93616.

A coded value specifying the countries from which participants will be, are intended to be,

or have been recruited for an activity. 